\title{
A Study on the Innovation of Teaching Management in Southwest Petroleum University
}

\author{
Xiangli Meng \\ School of Foreign Language, Southwest Petroleum University, Chengdu, China \\ Email: mxl2008@163.com
}

How to cite this paper: Meng, X. L. (2019). A Study on the Innovation of Teaching Management in Southwest Petroleum University. Creative Education, 10, 1063-1069.

https://doi.org/10.4236/ce.2019.106079

Received: April 24, 2019

Accepted: June 3, 2019

Published: June 6, 2019

Copyright $\odot 2019$ by author(s) and Scientific Research Publishing Inc. This work is licensed under the Creative Commons Attribution International License (CC BY 4.0).

http://creativecommons.org/licenses/by/4.0/

\section{(c) (i) Open Access}

\begin{abstract}
The level of teaching management in colleges and universities affects the quality of teaching management in colleges and universities, teaching quality in colleges and universities, and further affects the quality of personnel training in colleges and universities. At present, Southwest Petroleum University is strengthening the management of teaching and improving its management level. There are many factors affecting the teaching management level and quality of Southwest Petroleum University. As one of the main carriers of teaching management of Southwest Petroleum University, students have important theoretical and practical significance in improving the management level by evaluating the teaching management satisfaction and finding out the existing problems and solutions. This study first summarizes the problems existing in the daily teaching management, teaching guarantee management and teaching quality management of Southwest Petroleum University. Secondly, it analyses the causes of the problems. Finally, it puts forward the corresponding solutions to the problems and causes.
\end{abstract}

\section{Keywords}

Teaching Management, Innovation, Southwest Petroleum University, Higher Education

\section{Introduction}

The development of higher education has entered the stage of popularization, and colleges and universities have developed from the extension of enrollment expansion to the connotation. Colleges and universities have shifted to focus on quality development, especially the quality of personnel training. The quality of 
teaching management in colleges and universities affects the quality of teaching in colleges and universities, and further affects the cultivation of talents in colleges and universities (Li, 2015). As the main body of the university, whether the students are satisfied with the teaching management of the university is an important standard to test the quality of the teaching management of the university, which affects the development of the teaching management of the university. In 2004, according to the changes in higher education development, the Ministry of Education explained the standards of students' satisfaction in teaching evaluation. It further clarified that in teaching management services, students' wishes must be taken into account more to meet students' needs and provide students with satisfactory teaching management. College teaching is essentially a kind of student-oriented service. College students are becoming more and more aware of the satisfaction of teaching management (Liu, 2014). Colleges and universities must change their concepts, establish the concept of serving students, understand the situation of students' satisfaction with teaching management, and provide teaching management that meets the needs of students. Only by understanding the students' satisfaction with teaching management, can we know more clearly what problems exist in the teaching management of colleges and universities and what aspects need continuous improvement, deepen the teaching reform, meet the needs of students, promote the improvement of teaching management quality, and then improve the quality of teaching and personal training (Liu et al., 2012).

This research is based on the perspective of student satisfaction to explore teaching management issues (Yin, 2014). It has important theoretical and practical significance to take teaching management of Southwest Petroleum University as the evaluation object, take university students as the evaluation subject, and find out the problems of teaching management according to the students' satisfaction with teaching management, and put forward corresponding countermeasures and suggestions.

\section{Problems in Teaching Management of Southwest Petroleum University}

Southwest Petroleum University is the second petroleum undergraduate college founded in New China. It is a co-construction of the central and local governments and is mainly managed by the Sichuan Provincial People's Government. In 2013, the school was selected as one of the 100 universities in the "Basic Capacity Building Project of Universities in the Midwest of China". In September 2017, it was selected as the first batch of "double first-class" world-class discipline construction universities in China. On the basis of the investigation and analysis of teaching management based on students' satisfaction, according to the results reflected in the survey and the contents of interviews, through comprehensive and in-depth analysis, the problems are as follows:

1) The idea of teaching management is backward 
In the current process of teaching management in Colleges and universities, there are still some backward management concepts (Sun, Wang, Wang, Li, \& Li, 2012). First of all, teaching management in Colleges and universities follows the traditional management process. It cannot proceed from the actual situation of the school, formulate teaching plans according to the actual needs of the students. There exists the wrong idea of "task is more important than reality". It only pays attention to the teaching task of the school and ignores the "humanistic thought" that the students are the main body of teaching. Secondly, the teaching method emphasizes too much on management and supervision, does not consider the ideas and needs of the management subject, teachers do not have teaching enthusiasm, students do not have the initiative to learn. Finally, under the influence of this idea, the curriculum is not innovative, does not involve some new and cutting-edge knowledge, which is not conducive to the cultivation of students' innovative ability.

2) Imperfect management system

The smooth development of teaching management in Colleges and universities depends on the perfect management system, but at present, the management system in Colleges and universities is not perfect. Firstly, in the aspect of system establishment, the management system of some colleges and universities is not perfect, the system formulation cannot meet the learning needs of teachers and students, there are certain system defects; secondly, in the aspect of system implementation, there are problems of weak norms. Although some systems are stipulated, in the actual implementation process, they are "nominal and unreal". For example, in view of the requirements of moral, intellectual, physical and aesthetic development reflected in the management of teaching plan, teaching practice and students' teaching according to their aptitude, colleges and universities have corresponding system contents, but in the actual implementation process, students can not feel the existence of the system (Gomes, 2015).

3) The backward means of teaching management in Colleges and Universities

From the current situation of teaching management in Colleges and universities, the means of management are relatively backward. Although part of the management has been networked, the network construction is not perfect, and there are many manual operations. This will easily lead to a large workload and inefficiency of teaching management in Colleges and universities. It is not conducive to the development of teaching management in Colleges and universities, but also cause great inconvenience to teachers and students. Because of the backwardness of management means, some management methods still follow the traditional mode, such as standardizing students and teachers with unified standards. A single evaluation criterion can only lead to teaching conformity, teaching without innovation, and is not conducive to the cultivation of students' creativity.

4) The management team is uneven

In colleges and universities, teaching managers are generally ignored, not only 
as a job that does not require professional requirements, but also in terms of wages and salaries, there is a big gap with university teachers. The entry threshold of teaching managers in Colleges and universities is low, and most of them are part-time teachers and researchers in Colleges and universities. As a result, the professional knowledge of managers is not strong enough and their quality is uneven. Their own work is not valued, but also makes some managers germinate the idea of seeking better work, and the loss of staff is greater. 3. The main problems in the scientific research of College Counselors in Southwest Petroleum University.

\section{Cause Analysis of Problems in Teaching Management of Southwest Petroleum University}

1) There are deviations in teaching management concepts

The influence of the traditional administration system of teaching management in Colleges and universities is more manifested in the concept of "management". Nowadays, although the teaching management of colleges and universities gradually emphasizes the subjective consciousness of people and the transformation of management into service. However, teaching managers still carry out their thinking in the form of administrative execution orders by experience, emphasizing authority. There are insufficient and unequal exchanges and consultation between higher and lower levels of teaching management, between managers and teachers and students, between teachers and students.

2) Unscientific teaching management system

Teaching administrators of Southwest Petroleum University manage teaching according to teaching plan and task, but this kind of management emphasizes too much the process of management and neglects the effect of teaching management. The rigidity of the system lacks flexibility. In the teaching management, the formulation and revision of the teaching plan need to be implemented by the requirements of the professional talent training plan. However, the fact is that the educational authorities and schools have made many compulsory provisions, and the teaching departments can only make changes in a small scope.

3) Single teaching management

The prominent feature of teaching management in Colleges and universities is administrative management, which is efficient and mandatory and emphasizes the realization of goals. However, this management mode makes teaching management in a rigid state and lacks flexibility, which cannot meet the requirements of teaching reform and development in Southwest Petroleum University.

4) Lack of teaching management professionals

With the reform and development of Southwest Petroleum University, the professional competence and quality of university teaching managers are constantly improving. But there is still a big gap between the needs of teachers and students and the needs of teaching development. The lack of professionals in teaching management of Southwest Petroleum University is one of the impor- 
tant factors restricting teaching management.

5) Unscientific assessment of teaching management

There are unscientific aspects in the assessment of teaching management. First, the evaluation of teaching management pays attention to the effectiveness of the implementation of rules and regulations. The implementation of teaching management is strictly determined according to the implementation of rules and regulations, and the implementation of teaching management system is lack of rectification and monitoring after implementation. Teaching management assessment makes teachers busy with all kinds of checks and students cope with all kinds of random checks. Teaching management assessment becomes a burden, which not only does not effectively promote teaching, but also affects the teaching effect. In the teaching management, the differences between disciplines and specialties are not taken into account only according to the rules and regulations. The evaluation criteria cannot be different and uniform because of the different disciplines, lack of autonomy and differences, no specific and different settings for different majors, the setting of teaching management assessment is not scientific and specific enough, not detailed enough, and the rules and regulations of teaching management can easily become a waste. $\mathrm{Pa}$ per. Secondly, the assessment of teaching management is over-graded, and the evaluation of students' academic performance, including the evaluation of teachers, is based on quantitative scores. The evaluation of students mainly depends on scores, while the evaluation of teachers mainly depends on the amount of scientific research and teaching. As a result, students lose their interest in professional knowledge in pursuit of scores, and teachers lose their mindset of devoting themselves to research and teaching in pursuit of teaching and scientific research.

\section{Countermeasure of Teaching Management in Southwest Petroleum University}

1) Renewing the Concept of Teaching Management

Establish the people-oriented management concept, formulate teaching objectives and management system based on the actual situation of students and teachers, and emphasize humanization in management. Taking the school task as the assistant guidance of teaching management, putting the students' needs in the first place, so that teaching management can be truly implemented; teaching management requirements can mobilize teachers' enthusiasm and students' initiative. Teachers and students are regarded as the main body of management, not the passive, to achieve respect for teachers and students; innovate teaching management concepts, introduce some new management methods, innovate curriculum formulation, and achieve a new way of teaching management (Lima, 2002).

2) Improving the Management System

To innovate management system and change some traditional and unsuitable 
old systems, the establishment of management system should be closely combined with teaching practice. Southwest Petroleum University should constantly revise and improve the normative system, strictly act in accordance with the norms, improve all kinds of student status system and archives management system, student course selection system and credit system, so that students can really feel the advantages of the teaching management system, and truly provide convenience for students' learning; implement various systems of teaching management to achieve "well-known" and should not put all kinds of systems into practice. Du is only an ornament, so we should really play its role.

3) Scientific Management Means

With the development of computer network technology and the expanding application of network (Paro, 2003), teaching management should conform to the progress of technology and realize the networking of management. College management should make full use of the network, apply information technology to college teaching management, minimize manual labor and improve management efficiency. It is more and more obvious to formulate various assessment and evaluation methods. In order to cultivate innovative talents, it is necessary to formulate various assessment and evaluation methods. Only in this way can teachers give full play to their innovative ability and form a unique teaching style, and students learn rich and diverse knowledge (Passador \& Salvetti, 2013).

4) Improving the Quality of Managers

In order to improve the quality of teaching managers, we must first improve the management consciousness. Colleges and universities should attach great importance to management work, clarify the importance of its work, and strengthen the importance of managers. Secondly, in the process of recruiting managers, we should attach importance to the professional knowledge of managers, improve the entry threshold, reduce the part-time nature of managers, and generally improve the quality of managers. Thirdly, we should improve the salary treatment of managers, narrow the gap with teachers and scientific researchers, and recognize the value of managers. Finally, we should strengthen the training of managers, enhance their professional knowledge and improve their management ability.

\section{Conclusion}

The quality of teaching management in colleges and universities is directly related to the quality of teaching in colleges and universities, and further affects the quality of personnel training in colleges and universities. However, there are still many shortcomings in the teaching management of Southwest Petroleum University. The management cannot meet the needs of current development, and the management cannot keep pace with the times. Therefore, we should constantly improve the teaching management to escort the education work of Southwest Petroleum University. 


\section{Conflicts of Interest}

The author declares no conflicts of interest regarding the publication of this paper.

\section{References}

Gomes, A. V. A. (2015). Democratic Management in the National Education Plan 2014-2024. In A. V. A. Gomes, \& T. F. de Britto (Org.), National Education Plan: Construction and Perspectives (293 p). Brasilia: Chamber of Deputies, Chamber Editions: Federal Senate, Technical Editions (Series Works in Partnership, No. 8).

http://bd.camara.leg.br/bd/bitstream/handle/bdcamara/21659/plano_nacional_educaca o.pdf? sequence $=1$

Li, L. (2015). Full English Teaching for Teachers to Face New Challenges. 21st Century English Network (English Education Information, English Education Weekly Electronic Version)-11-10, Issue 18th. http://paper.i21st.cn/story/21407.html

Lima, L. (2002). School Organization and Radical Democracy: Paulo Freire and the Democratic Governance of the Public School (3rd ed.). Sao Paulo: Cortez.

Liu, F. (2014). Research on the Problems and Countermeasures of Bilingual Teaching in Colleges and Universities in Liaoning Province in the Process of Internationalization. New Course.Early, No. 7, 97-97.

Liu, H.S. et al. (2012). A Brief Talk on Bilingual Teaching of Microelectronics Course. Journal of Wuhan University (Science Edition), No. S2, 163-165.

Paro, V. H. (2003). Election of Directors: A Public School Experiences Democracy (2nd ed.). Sao Paulo: Shaman.

Passador, C. S., \& Salvetti, T. S. (2013). Democratic School Management and Critical Organizational Studies: Theoretical Convergences. Education and Society, 34, 477-492.

Sun, H. M., Wang, J. X., Wang, C. X., Li, X. Y., \& Li, N. Y. (2012). The Combination of Open Students International Vision and the Cultivation of Innovative Ability and the Introduction of Bilingual Teaching Mode-Taking the Course of Flower Cultivation Technology in Shenyang Agricultural University as an Example. Journal of Shenyang Agricultural University (Social Science Edition), 14, 87-91.

Yin, Y. (2014). Bilingual Teaching in Colleges and Universities: The Main Bridge towards the Internationalization of Higher Education in China. Journal of Jiangxi Institute of Science and Technology, No. 3, 24-28. 